\title{
Halina Bednarek-Ochyra and Ryszard Ochyra: A tribute to their contribution to bryology
}

Vítězslav Plášek

It is a great pleasure and honour for me to have the opportunity of editing this unique issue of Acta Musei Silesiae, Scientiae Naturales which contains some 16 bryological contributions dedicated to the well known and respected duo of Polish bryologists, Professors Halina Bednarek-Ochyra (Fig. 1) and Ryszard Ochyra (Fig. 2), on the occasion of their sixtieth and seventieth birthdays, respectively. By their extensive collections and their valuable work on bryophytes from almost all parts of the globe, they have provided a unique addition to the treasury of bryological knowledge. Their expertise and contributions span a wide spectrum of bryological research, including primarily systematics, bryogeography, nomenclature, as well as botanical iconography and documentation, and occasionally, also bryophyte conservation, cytology, ecology and palaeoecology. They are also editors of the valuable series of the Polish, African, Antarctic, Fuegian and Spitsbergen exsiccatae, which have contributed numerous rarities to the world's herbaria. One cannot fail to acknowledge their exceptionally extensive exploratory and editorial activities as well.
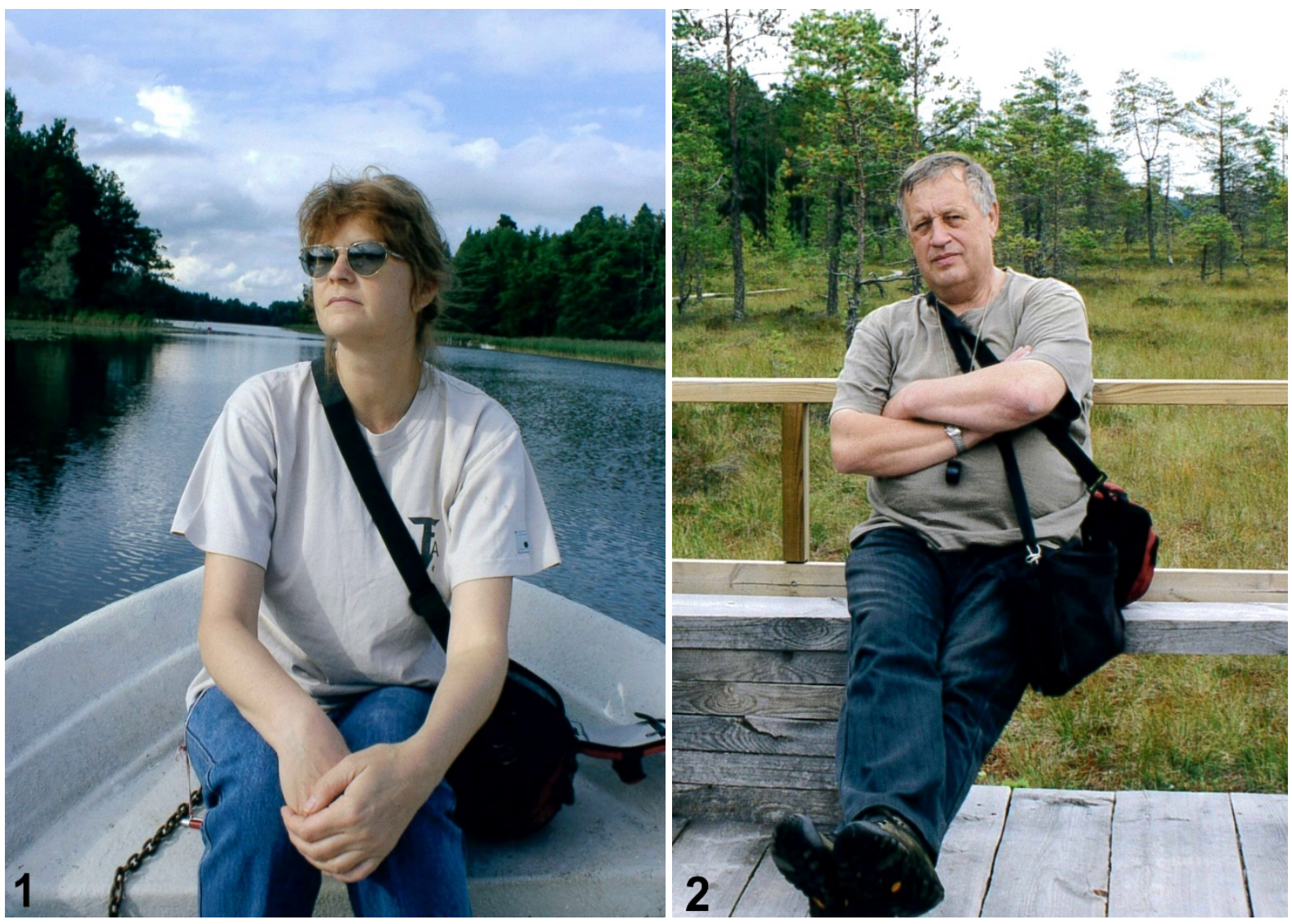

Fig 1: Halina Bednarek-Ochyra at Lohjajärvi lake in Lohja, Finland, on August 21, 2011 (Photo by R. Ochyra).

Fig 2: Ryszard Ochyra in Torronsuo Nat. Park, Finland, on August 22, 2011 (Photo by H. Bednarek-Ochyra). 
From the beginning of my bryological career I became well acquainted with the works of the Ochyra team but, because they mainly dealt with exotic bryophytes, their scientific accounts were less useful for me as a student of Central European bryophytes. My first meeting with them took place in Kraków in 2005, despite the fact that we began written contact, especially though an exchange of our own published articles, some two years earlier. From the beginning, both were always very kind and helpful - they freely shared literature, made revision of my own bryological collections, or just helped with valuable advice. At that time, I began to specialise in the study of epiphytic species from the genus Orthotrichum Hedw. and I needed to obtain non-European material of these bryophytes for comparison and study.

A first proposal for a common bryological expedition to the Southern Hemisphere was subsequently made. In 2013, we visited Tasmania and the South Island of New Zealand, including Stewart Island. This was followed by a visit to Patagonia, both the Chilean and Argentine parts. These expeditions, when Ryszard and Halina introduced me to a great many bryophyte taxa in the field, were a great benefit to my studies. Because the common style of field work suited us, we continued exploring bryophytes also in Asia. In 2015, we visited together and examined the bryophyte collections deposited in the three largest Chinese herbaria (KUN, PE, IFP - formerly IFSBH) and also made several trips to the mountain ranges in Yunnan. A year later, during a second expedition, we visited 12 provinces of mid-east China. These expeditions resulted in a large amount of bryological collections, but most of all, the wonderful moments spent with Halina and Ryszard and the many hours we spent in discussions on work and personal topics. Last but not least were a number of contributions to the scientific journals based on the specimens collected during our joint trips.

The scientific activity of Ryszard and Halina Ochyra is almost entirely related to the Institute of Botany of the Polish Academy of Sciences, which in 1986 was named W. Szafer Institute of Botany for its founder and first director, Professor Władysław Szafer (1886-1970). On the occasion of the 60th anniversary of the establishment of this institute in 2013, an extensive monograph was published presenting the history of its development and research (Godzik \& Wołowski 2013). It contained a separate, extensive chapter presenting in detail the history of the Laboratory of Bryology, which in large part was the history of their own scientific activity, because Ryszard had by then been associated with it for 41 years, from 1972, and Halina for 29 years from 1984 (Ochyra 2013). From this essay I also drew the most important biographical data of both jubilarians and the details of their scientific work, although I learned many important facts from their lives during numerous meetings with them.

Ryszard Ochyra was born on September 10, 1949, in Rozbórz near Przeworsk in Rzeszów Province in SE Poland, where he graduated from primary and secondary schools. During this time, he divided his interests between history, archeology and biology. In the end, he decided to study biological science and in 1967 he enrolled at the Faculty of Biology and Earth Sciences of the Jagiellonian University in Kraków. Here again, he initially faced some personal dilemmas because he was tempted by modern spontaneously developing disciplines, such as biochemistry and ecology, but was irresistibly attracted to closer contact with nature, as he had been throughout his childhood and youth in his native village, which he missed more and more while living in the big city. Finally, it was botany which best suited his personality, especially as there was a chance to pursue graduate work in the region where he was born. He completed his master's dissertation entitled "Changes in the flora of meadows and fens in the south-eastern part of the Kotlina Sandomierska basin" under the supervision of Professor Jan Kornaś (1923-1994), head of the Department of Plant Taxonomy and Phytogeography of the Institute of Botany of the Jagiellonian University and defended it on 24 June 1972, receiving a Magister (Master of Science) degree.

Before the completion of his studies at the Jagiellonian University there was an event which was to have considerable influence on Ryszard Ochyra and his calling to bryology. In search 
of employment he went to the Institute of Botany of the Polish Academy of Sciences which shared the same complex of buildings. The then director of the latter institute, Professor Adam Jasiewicz (1928-2001), stated that there was a possibility of obtaining a position there, provided he could deal with bryophytes. At the time no one continued to work there on these plants and he wanted to revive the study of bryophytes in the institute. For several months he was employed on temporary contracts in the Laboratory of Bryology and Lichenology but, unfortunately, at that time it was impossible to obtain a permanent job for a bryologist. However, this first contact with a Laboratory, which had such great traditions of bryological research and having large herbarium collection of bryophytes, was enough to "infect" a young man with "bryophily".

During the next four years, in 1972-1976, as a postgraduate student at the Faculty of Biology and Earth Sciences of the Jagiellonian University, Ryszard pursued his doctoral dissertation dealing with the vegetation of karst sink-holes in the vicinity of Staszów in the Małopolska Upland where bryophytes played an important role in peatland plant communities. He successfully defended his doctorate on 11 May 1976 and earned a Ph.D. degree in Biological Sciences. The doctoral dissertation was published in 1985 (Ochyra 1985) and was awarded by the Minister of Science and Higher Education. While completing his doctorate Ryszard continued his studies on bryophytes as a self-taught person because no bryologist was then in Kraków and only occasionally he contacted Professor Kazimierz Karczmarz (1933-2011) in the Marie Curie-Skłodowska University in Lublin. His efforts were so effective that when he was employed in the then Laboratory of Bryology and Lichenology of the Institute of Botany of the Polish Academy of Sciences on October 20, 1976, he was able to start fully independent scientific activity in the field of bryology. In fact, during his postgraduate studies Ryszard was in constant contact with this institution, because the bryophyte herbarium of KRA was on permanent loan at KRAM and Ryszard had unlimited access to it and held informal curatorship over it.

The first three years of work Ryszard devoted primarily to the formation of a modern research laboratory, establishing contacts with local and foreign researchers, ordering and enlarging herbarium collections, and above all filling gaps in literature generated during the stagnation period in bryological studies at this institution and, of course, improving his knowledge of bryophytes. He conducted extensive field research in the Carpathians and in north-eastern Poland and he also initiated a new series of exsiccata-Musci Poloniae Exsiccati. In addition, he established a close cooperation with Piotr Szmajda from the Department of Geobotany at Adam Mickiewicz University in Poznań, who was working towards developing an atlas of the geographical distribution of mosses in Poland. One of the first effects of this cooperation was the publication of the first, updated checklist of mosses in Poland (Ochyra \& Szmajda 1978).

A turning point in Ryszard's scientific career was his participation in the 4th Antarctic Expedition of the Polish Academy of Sciences to King George Island in the South Shetland Islands (1979-1980). Working with the bryophytes of this previously poorly studied region of the Earth was a great challenge. It meant the need to become familiar with the taxonomic and phytogeographical problems of exotic bryophytes, but at the same time it was a great opportunity to begin research on mosses on a truly global scale. As a distant goal of his research, Ryszard set out to develop descriptive Floras of the mosses of King George Island and the entire Antarctic continent. All his subsequent scientific activities were subordinated to this goal. Thus began a cosmopolitan approach to his research that has extended to bryophytes from practically all parts of the globe. Apart from his investigations on Antarctic bryophytes, he initiated studies on African tropical mosses obtained from various Polish collectors. He took his first steps in African bryology under the guidance of Professor Tamás Pócs of Eger and Vácrátót, Hungary, an eminent expert in African bryophytes, whom he first met in 1978. Their close cooperation 
and friendship has continued for over forty years.

In 1982, Professor Jan Kornaś told Ryszard that he had a student who wanted to complete her master's thesis on mosses. At the Jagiellonian University there was still no specialist in this group of plants, so he asked Ryszard whether he would take on the scientific supervision, including proposing the subject of her master's thesis. It was to be informal supervision, because the then regulations did not allow a master's thesis to be supervised by a scientist from outside the university. At this time Ryszard, together with his friend Dr Piotr Szmajda, had started the implementation of a long-term project Atlas of the geographical distribution of mosses in Poland (ATMOS) which constituted Series V of Atlas of the distribution of spore plants in Poland, a vast project initiated in 1962 by Professor Zygmunt Czubiński (1912-1967) in Poznań which intended to map the distribution of all groups of spore plants in Poland. They published the first part of this atlas (Ochyra \& Szmajda 1983) and since only a few bryologists were active in Poland at that time, they felt that anyone willing could be welcome to cooperate in this huge project. In this way Halina Bednarek went to the then Laboratory of Bryology and Lichenology.

Halina Bednarek was born on August 16, 1959, in Częstochowa in Katowice Province in Central Poland, where she spent her childhood and early youth and completed her basic education. From the very beginning she had particularly strong botanical interests and in 1979 she began her biological studies at the Faculty of Biology and Earth Sciences of the Jagiellonian University in Kraków. Thus, in a natural way, Halina went to the Institute of Botany at that university, and from there to the Laboratory of Bryology and Lichenology at the Institute of Botany of the Polish Academy of Sciences. As the subject of her master's thesis, Ryszard proposed that she could study the geographical distribution of seven species of relict glacial mosses in Poland. The project was accepted by Professor J. Kornaś but this work was to be formally performed under the official supervision of a mycologist, Professor Barbara Gumińska. Halina turned out to be a very good student deeply involved in her research and consistently carried out the tasks set before her. As a result, she completed an excellent treatment which was prepared in the style adopted in the ATMOS and the species studied by her were included in the third part of this series (Ochyra et al. 1988). Halina defended her master's thesis on 15 June 1984 and from the first of October of that year she began her postgraduate studies in the Institute of Botany of the Polish Academy of Sciences. On 1 December 1987 she was employed full-time at the Institute. Very early on, Halina also revealed her extraordinary talent as a botanical illustrator, which turned out to be her second "trademark" in addition to her activities as a moss systematist. She has completed a great many plates of mosses and liverworts, illustrating almost all their publications.

On March 8, 1986, Halina Bednarek and Ryszard Ochyra were married and since then their scientific careers have strictly overlapped and have been closely aligned. In June 1991, they welcomed into their lives a daughter, Katarzyna, who is now a medical doctor residing in Kraków. In the mid-1980s, Ryszard worked intensively on a taxonomic revision of the genus Sciaromium (Mitt.) Mitt. (Ochyra 1987a, b, c, d) which was the subject of his habilitation thesis. He earned his D.Sc. (habilitation) degree in 1988 at the Jagiellonian University and in Poland this degree was then a required formal qualification to independently teach and/or examine a designated subject at the university or research institute level. For his habilitation thesis, Ryszard was awarded in 1987 the prize of the Division of Biological Sciences of Polish Academy of Sciences. In 1993, five years after earning the D.Sc. degree, the President of the Republic of Poland awarded Ryszard Ochyra the title of Professor of Natural Sciences. Between 1976 and 1993 he served as the Curator of Bryophytes in KRAM and between 1989 and 2013 he led the Laboratory of Bryology. In 2017 he formally retired but at the same time he was employed in the Institute of Botany on a contract which expired on 31 December 2019. 

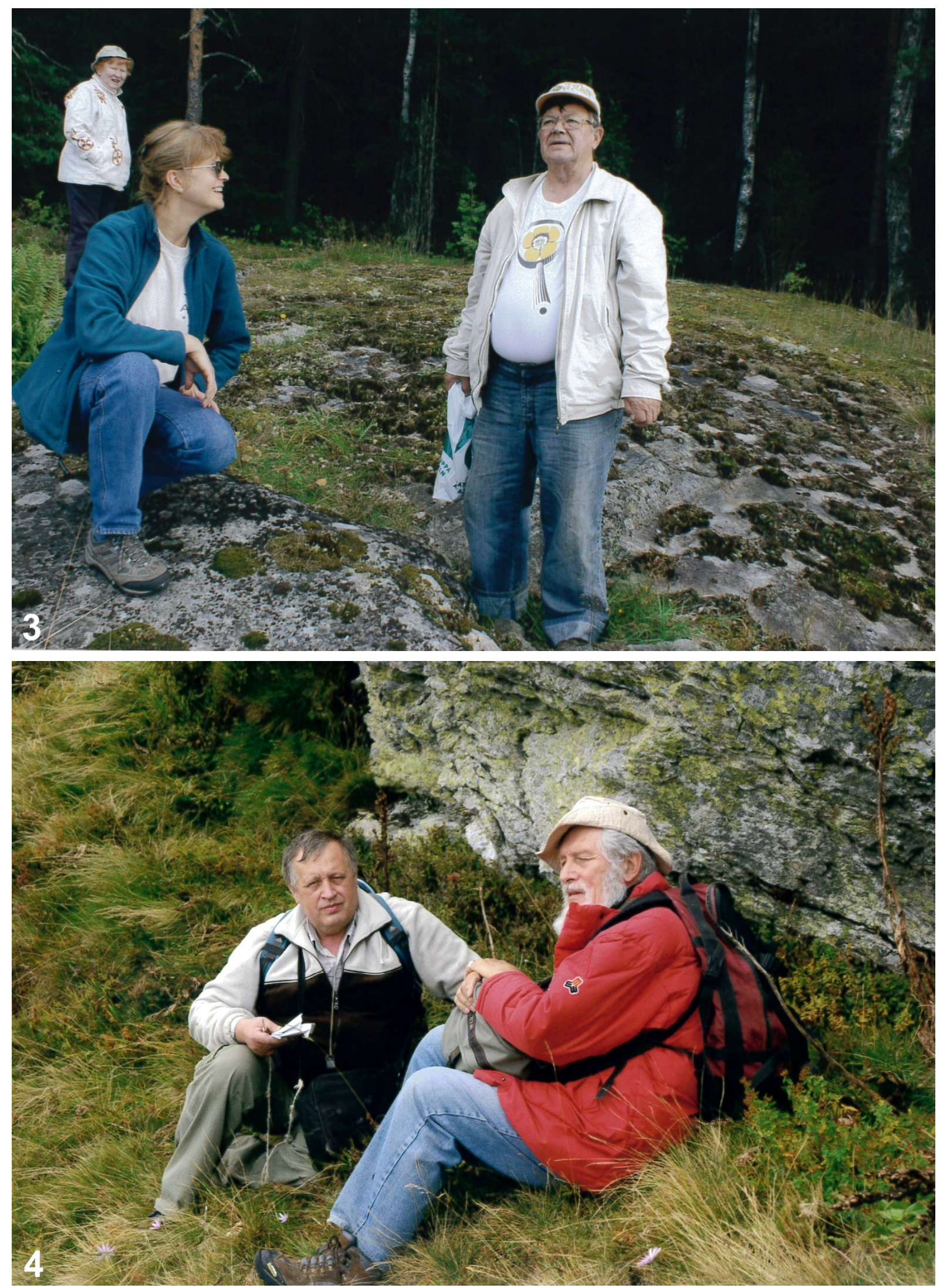

Fig 3: Halina Bednarek-Ochyra with Aune and Timo Koponen and his wife in on the shore of Lohjajärvi,

Finland, on August 21, 2011 (Photo by R. Ochyra).

Fig 4: Ryszard Ochyra with Tamás Pócs at the summit of Cucurbăta Mare in the Bihor Mts, Romania, on September 17, 2010 (Photo by H. Bednarek-Ochyra). 
Halina initially intended to continue her research on the distribution of mosses in Poland, with particular reference to the mountain moss taxa occurring on relictual stations on adjacent uplands and lowlands. This project was to be the subject of her doctoral dissertation. The results of these studies were published in five subsequent parts of the Atlas of the geographical distribution of mosses in Poland (Ochyra et al. 1990a, b, 1993, Szmajda et al. 1991, BednarekOchyra et al. 1994). However, while developing her studies on species of Racomitrium Brid., this genus attracted her special interest when she became aware of a lot of unresolved taxonomic problems, both in its European and exotic species. The result of her in-depth studies of this genus was a comprehensive monograph of Racomitrium in Poland, which contained also a world synopsis of the genus and the first attempt at its infragenetic classification (BednarekOchyra 1995). This study became the subject of her doctoral dissertation which she defended on 13 June 1995 and in the next year it was awarded by the Division of Biological Sciences of the Polish Academy of Sciences.

Because the traditionally conceived genus Racomitrium was a very heterogeneous taxon, it was split into four segregates (Ochyra et al. 2003) in the new catalogue of Polish mosses which contained many taxonomic and nomenclatural novelties. Halina completed a world taxonomic monograph of Codriophorus P.Beauv., the second largest segregate of Racomitrium, which was the subject of her habilitation thesis (Bednarek-Ochyra 2006). She earned her D.Sc. (habilitation) degree on 20 February 2007 in the W. Szafer Institute of Botany of the Polish Academy of Sciences and her monograph was again awarded in 2008 by the Division of Biological Sciences of the Polish Academy of Sciences. In 2011, four years after earning her D.Sc. degree, Halina received the Professorship in Natural Sciences from the President of the Republic of Poland. Since 1993 Halina has been the Curator of Bryophytes in KRAM and since 2019 she has been the head of the Department of Bryology. She still continues her monographic studies on the broadly understood Racomitrium and currently she is working towards a monograph of Bucklandiella Roiv., the largest segregate of this heterogeneous genus. This study is based not only on classical morphological and anatomical studies, but she has revised her species concepts when molecular evidence has suggested alternative solutions (BednarekOchyra et al. 2014; Sawicki et al. 2015).

Although Ryszard always had a cosmopolitan approach to his taxonomic studies and worked on moss taxa from all parts of the world, from the very beginning his work was subordinated to a major goal, which was the descriptive Flora of Antarctic mosses. In his numerous analytical works, he clarified the taxonomic status of nearly all species described from the southern polar regions. The first result of this study was a descriptive Moss Flora of King George Island, where he began his great adventure with bryophytes of the Southern Hemisphere (Ochyra 1998). This Flora was recognised as an outstanding scientific achievement and in 2000 Ryszard received the Prime Minister's Award for it. In the meantime, Halina received a grant from the Polish State Committee for Scientific Research for the development of the Antarctic liverwort flora. In collaboration with J. Váňa (Prague) and R. I. Lewis Smith (Cambridge), the Ochyras completed the first Flora of these plants in the Antarctic (BednarekOchyra $i$. 2000). The next eight years were focused on the development of a similar Flora of Antarctic mosses. As a result, a mammoth opus was published (Ochyra et al. 2008) which was superbly illustrated by Halina. For these illustrations, in 2009 she was awarded the Jill Smythies Medal by the Linnean Society in London, and in 2011 the International Association of Bryologists awarded this Flora The Hattori Prize for the best bryological publication for the period of 2009-2011. Additionally, this Flora was recognised as an outstanding scientific achievement and in 2009 Halina and Ryszard received the Award of the Division of Biological Sciences of the Polish Academy of Sciences for it.

Halina and Ryszard are not typical herbarium based taxonomists, but they try to know the species studied in their natural environment and to work on specimens collected in the field 
by themselves. Therefore, they have undertaken numerous expeditions to the remote regions of the Earth. Ryszard initiated his field studies in the austral cool and cold regions in 1979-1980 when he worked in the Antarctic and on the Falkland Islands. In 1995 he bryologised on Isla Grande de Tierra del Fuego and subsequently explored some other subantarctic islands, including the Prince Edward Islands (1999, 2001, 2003), Îles Crozet (2006, 2012) and Îles Kerguelen (2006-2007). These archipelagoes had been largely undercollected and most taxonomic concepts of the species had been based on just a few specimens collected in the nineteenth century. In 1988, Halina and Ryszard were invited by Tamás Pócs to Tanzania and together they explored many sites in this East African country including, among others, the Uluguru and Kilimanjaro Mountains and Mount Meru. In 2009, they visited Africa again and carried their further field studies in Namaqualand and in the Richetrsveld National Park and in the Western Cape. Earlier, in 2007, Ryszard had conducted field research in Mpumalanga (earlier Transvaal) with Dr Jacques van Rooy of Pretoria. In 2013, Halina and Ryszard studied the moss flora of Tasmania, the South Island of New Zealand and Stewart Island, and in 2015 they collected in the Patagonian region of Chile and Argentina.

There was no need to wait long for the next joint field trips. In 2015, the University of Ostrava has established a cooperative agreement with the Shanghai Normal University and thanks to financial support of Moravian-Silesian Regional Authority in Ostrava I was able to offer Halina and Ryszard research trips to China. During three trips in 2015, 2016 and 2017 we were able to conduct field research in Yunnan, Sichuan and in many central-east provinces of this huge country. These expeditions were especially enjoyable for Halina, who is a great lover of Chinese culture and art, as well as the culinary delights in which our tastes were very much in line. Of course, she could see and collect many species of her beloved racomitialean mosses.

During nearly fifty years of their activity, Halina and Ryszard Ochyra have developed a large bryophyte herbarium in the Institute of Botany of the Polish Academy of Sciences (KRAM). When Ryszard started his work in this herbarium in 1972, it consisted of about 25,000 accessioned specimens. Thanks to an extensive exchange of herbarium specimens, numerous donations of specimens from Polish bryologists, as well as their own collections, the herbarium now contains a quarter of a million specimens and it is the largest herbarium of bryophytes in Poland. A considerable part of this herbarium represents the personal collection of bryophytes made by Ryszard and Halina, consisting of over 50,000 specimens.

Because Halina and Ryszard were employed in a research institute that did not conduct any didactic activity, their contacts with students were very limited. During his academic career, Ryszard served as a guest supervisor for six master's theses of students from the Jagiellonian University. Unfortunately, only one of the students continued her scientific activity in bryology. This exception was Halina. Ryszard supervised two doctoral theses. In 1994, Dr Lidia Gos prepared under his guidance a doctoral thesis on a taxonomic revision of the genus Seligeria Bruch \& Schimp. in Europe. Unfortunately, after receiving her Ph.D. degree she could not get a job at the University of Gdańsk and is no longer involved with bryology. His second student, Dr Ewa Fudali, prepared a doctoral dissertation under his supervision devoted to flora and distribution of bryophytes in the City of Szczecin in NW Poland. She defended this in 1996 and nowadays she continues successfully her bryological activity at the University of Environmental and Life Sciences in Wrocław. Halina, in 2010, promoted Dr Bartłomiej Hajek of the Faculty of Biology of Gdańsk University and he received his Ph.D. degree on the basis of a dissertation on the influence of forest management on the diversity and structure of the bryoflora of the beech forests in the Tricity Landscape Park. Currently, he occupies a position of the curator of bryophytes at GDA.

Ryszard Ochyra has had a very full and productive life and is one of the most prolific bryologists. In the years 1974-2019 he has completed 1580 publications, including 760 mono- 
graphs, books and scientific papers and notes, as well as 820 reviews, abstracts, reports, communications, indexes, translations, prefaces and editorials. A full bibliography of his publications is available at https://botany.pl/images/who_pl/BedOch/Ochyra-Bibliography.pdf. Ryszard Ochyra has described or coauthored 35 new genera, 30 new suprageneric taxa and 48 new species of mosses, as well as proposing 783 new taxonomic combinations. A full list of the new taxa, names and combinations for bryophytes published by Ryszard Ochyra in 19782018 is available at https://botany.pl/images/who_pl/BedOch/Ochyra_New-Names.pdf. In his honour, four genera of mosses, orchids and fossil bryophyte and thirteen bryophyte and vascular plant species and varieties have been named, including a few more in this volume. When speaking about his scientific achievements, it is impossible not to also mention his editorial activity. In the years 1990-1996 he was the editor or co-editor of the scientific journals Fragmenta Floristica et Geobotanica, Fragmenta Floristica et Geobotanica Series Polonica and Atlas of the geographical distribution of mosses in Poland. Since 2002 he serves as an associate editor of Cryptogamie, Bryologie, the oldest bryological journal published by the Natural History Museum in Paris, in which he is responsible for publications dealing with African and Antarctic bryology. All the papers edited by Ryszard Ochyra amount to nearly 10,000 printed pages.

The scientific output of Halina Bednarek-Ochyra is slightly more modest, but nevertheless very significant. In total, in the years 1987-2019 she has published 443 scientific works, mainly on taxonomy and biogeography of bryophytes, including 13 monographs published in bookform, 199 original scientific articles and chapters in books, 198 short phytogeographical notes published in 43 collective articles, 9 schedae for exsiccatae and 24 reviews, indexes and popular articles.A full bibliography of her publications is available at https://botany.pl/images/who_pl/ BedOch/Bednarek-Ochyra_Bibliography.pdf. In the period from 1991-2016 she has described 44 new taxa of bryophytes, including 1 subclass, 1 subfamily, 5 genera, 1 subgenus, 8 sections, 12 subsections and 20 species, as well as proposing 205 new combinations and 1 new species name. A full list of new taxa, names and combinations for bryophytes published by Halina Bednarek-Ochyra is available at https://botany.pl/images/who_pl/BedOch/Ochyra_NewNames.pdf. In her honour one species, Schistidium halinae Ochyra, was described and a few more are added in this volume.

\section{References}

Bednarek-Ochyra H. (1995): Rodzaj Racomitrium (Musci, Grimmiaceae) w Polsce: taksonomia, ekologia i fitogeografia [The genus Racomitrium (Musci, Grimmiaceae) in Poland: taxonomy, ecology and phytogeography]. - Fragmenta Floristica et Geobotanica Series Polonica 2: 1-307 [in Polish with extensive English summary].

- (2006): A taxonomic monograph of the moss genus Codriophorus P. Beauv. (Grimmiaceae). Polish Academy of Sciences, Institute of Botany, Kraków, 276 pp.

Bednarek-Ochyra H., Ochyra R. \& Szmajda P. (1994): Atlas of the geographical distribution of spore plants in Poland. Series V. Mosses (Musci). Part 9. W. Szafer Institute of Botany, Polish Academy of Sciences, Kraków and Adam Mickiewicz University, Poznań, 72 pp. + 10 maps (folio) [in English and Polish].

Bednarek-Ochyra H., Ochyra R., Sawicki J. \& Szczecińska M. (2014): Bucklandiella seppeltii, a new species of Grimmiaceae from Australasia, and its phylogenetic position based on molecular data. - Turkish Journal of Botany 38: 1214-1228.

Bednarek-Ochyra H., Váňa J., Ochyra R. \& Lewis Smith R.I. (2000): The liverwort flora of Antarctica. Polish Academy of Sciences, Institute of Botany, Cracow, xvi + $236 \mathrm{pp}$.

Godzik B. \& Wołowski K. (eds). (2013): Historia badań i rozwoju Instytutu Botaniki im. W. Szafera Polskiej Akademii Nauk (1953-2012) [History of the research and development of the W. Szafer Institute of Botany, Polish Academy of Sciences (1953-2012)]. Instytut Botaniki im. W. Szafera, Polska Akademia Nauk, Kraków, 438 pp. [in Polish]. 
Ochyra R. (1985): Roślinność lejków krasowych w okolicach Staszowa na Wyżynie Małopolskiej [Vegetation of the karst sink-holes in the vicinity of Staszów on the Małopolska Upland]. - Monographiae Botanicae 66: 1136 [in Polish with English summary].

- (1987a): A revision of the moss genus Sciaromium (Mitt.) Mitt. I. General remarks and the section Aloma Dusén. - Journal of Bryology 14: 453-464.

- (1987b): A revision of the moss genus Sciaromium (Mitt.) Mitt. II. The section Limbidium Dusén, with a description of Vittia gen. nov. (Vittiaceae fam. nov.). - Journal of the Hattori Botanical Laboratory 62: 387-415.

- (1987c): A revision of the moss genus Sciaromium (Mitt.) Mitt. III. The section Platyloma Broth. - Journal of the Hattori Botanical Laboratory 63: 107-132.

- (1987d): A revision of the moss genus Sciaromium (Mitt.) Mitt. - corollarium. - Bulletin of the Polish Academy of Sciences, Biological Sciences 35: 33-45 [with Russian summary].

- (1998): The moss flora of King George Island, Antarctica. Polish Academy of Sciences, W. Szafer Institute of Botany, Cracow, xxiv +279 pp.

- (2013): Pracownia Briologii [Laboratory of Bryology], 53-108 pp. In: Godzik B. \& Wołowski K. (2013): Historia badań i rozwoju Instytutu Botaniki im. W. Szafera Polskiej Akademii Nauk (1953-2012) [History of the research and development of the W. Szafer Institute of Botany, Polish Academy of Sciences (1953-2012)]. Instytut Botaniki im. W. Szafera, Polska Akademia Nauk, Kraków [in Polish].

Ochyra R. \& Szmajda P. (1978): An annotated list of Polish mosses. - Fragmenta Floristica et Geobotanica 24: 93-145 [with Polish summary].

- (1982): Mosses (Musci). In: Szweykowski J. \& Wojterski T. (eds), Atlas of [the] geographical distribution of spore-plants in Poland. Series V. Part 1. Państwowe Wydawnictwo Naukowe, Warszawa - Poznań, 31 pp. + 11 maps (folio) [in Polish and English].

Ochyra R., Lewis Smith R.I. \& Bednarek-Ochyra H. (2008): The illustrated moss flora of Antarctica. Cambridge University Press, Cambridge, xvii +685 pp. + [24 unnumbered pp. with plates].

Ochyra R., Bednarek-Ochyra H. \& Szmajda P. (1990a): Atlas of the geographical distribution of spore plants in Poland. Series V. Mosses (Musci). Part 5. W. Szafer Institute of Botany, Polish Academy of Sciences, Kraków and Adam Mickiewicz University, Poznań, 52 pp. + 10 maps [in English and Polish].

- (1990b): Atlas of the geographical distribution of spore plants in Poland. Series V. Mosses (Musci). Part 6. W. Szafer Institute of Botany, Polish Academy of Sciences, Kraków and Adam Mickiewicz University, Poznań, 50 pp. + 10 maps [in English and Polish].

Ochyra R., Szmajda P., Bednarek-Ochyra H. (1992): Atlas of the geographical distribution of spore plants in Poland. Series V. Mosses (Musci). Part 8. W. Szafer Institute of Botany, Polish Academy of Sciences, Kraków and Adam Mickiewicz University, Poznań, 80 pp. + 10 maps [in English and Polish].

Ochyra R., Żarnowiec J., Bednarek-Ochyra H. (2003): Census catalogue of Polish mosses. Polish Academy of Sciences, Institute of Botany, Kraków, 372 pp.

Ochyra R., Szmajda P., Bednarek H. \& Bocheński W. (1988): Atlas of the geographical distribution of spore plants in Poland. Series V. Mosses (Musci). Part 3. Państwowe Wydawnictwo Naukowe, Warszawa - Poznań, 61 pp. + 11 maps (folio) [in English and Polish].

Sawicki J., Szczecińska M., Bednarek-Ochyra H. \& Ochyra R. (2015): Mitochondrial phylogenomics supports segregates of Racomitrium (Bryophyta, Grimmiaceae). Nova Hedwigia 100: 293-217.

Szmajda P., Bednarek-Ochyra H. \& Ochyra R. (1991): Atlas of the geographical distribution of spore plants in Poland. Series V. Mosses (Musci). Part 7. W. Szafer Institute of Botany, Polish Academy of Sciences, Poznań and Adam Mickiewicz University, Poznań, 52 pp. + 10 maps. [in English and Polish].

Author's address: Vítězslav Plášek, Dept. of Biology and Ecology, University of Ostrava, Chittussiho 10, CZ-710 00 Ostrava, Czech Republic. E-mail: vitezslav.plasek@osu.cz 